\title{
The Geometric Principles of Warped Rib Vaults in Central European Baroque Architecture from Guarini to the Dientzenhofer Family and Balthasar Neumann
}

\author{
Víctor Compán • Margarita Cámara • \\ Francisco González de Canales
}

Published online: 15 January 2015

(C) Kim Williams Books, Turin 2015

\begin{abstract}
The aim of this paper is to identify the processes that brought about the development of the innovative continuous surfaces that shelter some of the masterpieces of Central European Baroque architecture. In order to achieve this, an evolutionary analysis is presented. It begins with some of the premises of Baroque architecture, the precedents of which can be found in the works and geometric studies of Guarino Guarini. This is followed by a study of the works of the Dientzenhofer family and Balthasar Neumann, underlining the principles behind and the description of warped ribs, which appear in their designs for the first time in architecture history, and which enabled the construction of their complex vault structures.
\end{abstract}

Keywords Central European Baroque architecture - Guarino Guarini ·

Dientzenhofer · Balthasar Neumann · Warped rib ·

Brick masonry structures

\footnotetext{
V. Compán $(\bowtie) \cdot$ M. Cámara

Department of Building Structures and Ground Engineering,

E.T.S.A.S. School of Architecture, University of Seville,

Avda. Reina Mercedes, 2, 41012 Seville, Spain

e-mail: compan@us.es

M. Cámara

e-mail: mcamara@us.es

F. González de Canales

Department of Architectural History, Theory and Composition,

E.T.S.A.S. School of Architecture, University of Seville,

Avda. Reina Mercedes, 2, 41012 Seville, Spain

e-mail: currocanales@us.es
} 


\section{Introduction}

The Baroque period changed the relationship that had existed up until then between man and space. Geometry was still believed to be the right tool to approach reality, no longer through the closed and finite geometric shapes of the Renaissance, but rather through infinite, dynamic, open and elusive extensions of space, expressions that claimed individual freedom in this new perception of the world's geometry. During the Baroque period, the world was conveyed through a cosmological order that, while comprehensible as a whole, each individual could navigate freely. The Baroque architecture of sacred spaces epitomizes this new mentality, and hence Baroque churches tend to be spatially continuous. This stands in contrast to the sacred spaces of the Renaissance, which were treated as a separate entities, complete in themselves. Baroque successions kept all spatial units in relation to one another, to such an extent that they became a fluid, complex and single entity. To take this notion to the vaults of buildings required interesting geometric operations in the transition between spatial surfaces, techniques which were at the forefront of the geometrical and technological knowledge of the time.

This present paper is divided into the following parts. The first part depicts the historic context, in order to show the goals laid out for the spaces of Baroque church. The second part is a review of the designs and geometric strategies employed by Guarino Guarini, the starting point for the development of Central European Baroque sacred architecture. The third part is an analysis of the main geometric and compositional assumptions that characterized the design of the most notable churches of Bohemian Baroque architecture. In this chapter we will look at the designs of the Dientzenhofer Family, who experimented with Guarino Guarini's legacy. The following part is a discussion of how Balthasar Neumann's work in Germany introduced further innovations into previous Central European Baroque experiments, and we analyze his three most outstanding designs. Finally, some concluding remarks are presented.

\section{A New Model Church for the Counter-Reformation}

After the Council of Trent (1545-1565) and the unfolding of the CounterReformation, the aspirations of the Roman Catholic Church focused on deep internal reform in order to stop the advance of Protestant doctrines. This included new approaches to the spatial conception of temples in order to comply with the new liturgical needs that the Tridentine Mass established: a standard rite to be performed by all Catholics as described in Pius V's Roman missal (1570) and which aimed to go back to "the original form and rite of the holy Fathers" (Pius V 1570). With the exception of Pietro Cataneo's I quattro libri dell'architettura of 1554 all other major Renaissance authors of architectural treatises (especially Alberti and Palladio) recommended the central plan for religious buildings. This particular layout was considered to embody the perfection of the circle as an image of the divine reason. Centralized churches were thus a "characteristic expression" of the 
architecture of the Renaissance (Evans 1995: 3-6). However, with the dawn of the Counter-Reformation, the ideal of perfection sought in central plan compositions throughout the fifteenth and sixteenth centuries was soon questioned. For counterreformers, central plan churches were considered a recent pagan import from the Age of Humanism, and not part of the general larger tradition of the Roman Catholic Church (Sinding-Larsen 1965: 203; Voelker 1977: 8). In addition, central plan churches did not fit in with the new liturgy of the Tridentine Mass. In fundamental parts of the rite, such as the consecration, all devotees, including the priests, had to face the altar. This required long spaces in order to allow frontal views of the altar for the large crowds that attended the liturgy. As a consequence, the search for the compositional scheme par excellence for the Counter-Reformation church meant retracing its roots back to the ancient basilica-to be more precise, to the deployment of single long spaces.

Even though central plan churches were widely preferred during the Renaissance, there were also remarkable exceptions before Trent that would serve as important references for the churches to come. Thus, for instance, in 1462, Leon Battista Alberti, who in his De Re Aedificatoria (1452) advocated that the shape of sacred buildings should follow the geometry of the circle, designed his most important church, Sant' Andrea in Mantua, by using the layout of a basilica. However, this reference is controversial as his choice for the basilica plan depended on very specific circumstances. According to most scholars, Alberti's original design was influenced by the constraints of the site. The need to incorporate an existing tower of the monastery church led him to explore alternative classical references such as Vitruvius's description of the Etruscan temple (Tavernor 1998: 159-178; Rykwert and Engel 1994: 216-217). Scholars also argue that the Latin cross plan we see today was not part of Alberti's original design (Tavernor 1998: 1964-1966; Rykwert and Engel 1994: 218-219); and that the strong tendency towards centrality in its plan and section, shown as a progression of finite proportional ratios, relates back to Alberti's general interest in circular compositions (Volpi Ghirardini 2015; Rykwert and Engel 1994: 221-224).

By the second half of the sixteenth century every architect's obsession had become to be able to merge the two major classical references for church designs: the Pantheon and the Basilica of Maxentius. Such an effort is epitomized, for instance, in the different variations of the most important temple under construction at the time: the Basilico of St. Peter in Rome. However, the church of the Gesù of 1568-1580, Giacomo Vignola's design for the church of the Jesuits in Rome, was to become the inevitable reference for all the new schemes that strove to find a compromise between the longitudinal and a central plan composition. Vignola based his design on a Latin cross plan shaped by one single large nave with adjacent lateral chapels. The main altar was in the apse, as was traditional in the Western Christian tradition, and two secondary altars were located at the two ends of the transept. With this solution, Vignola was not only able to integrate the liturgy of Trent-2 years before Pius V's new missal was issued-but also provided the church with a vast, fluid and continuous space cable of showcasing the CounterReformation spectacle. 
In all probability Charles Borromeo had the Gesù in mind when he wrote what would become the most influential book for the design of Baroque Churches throughout the following century: Instructiones Fabricae el Supellectilis Ecclesiasticae, first published in 1577 (Blunt 1962: 129; Voelker 1977). As the nephew of Pius IV, Borromeo was a very active spokesman and promoter of the Council's new decrees. His architecture was considered a fundamental means of CounterReformation propaganda, and with this text, he decided to make the single most important contribution to church architectural design. In Instructiones, Borromeo recommended going "back to the origins" of the Ancient Roman Basilica and he advocated the use of the "cruciform plan", and in particular, the "oblong cross" (the Latin cross) (Voelker 1977: 6). More importantly, as a response to the lack of décor of the Protestant rites, Borromeo proposed that Catholic churches should have an "imposing appearance" (Voelker 1977: 6), and in general, throughout the Instrucciones he expressed that religious services should aim at impressing the masses with their "magnificence" and "splendor", bringing about awe even to those who merely visited the church (Blunt 1962: 130-131).

Borromeo's preference for the longitudinal space of the traditional Old Roman Basilica and his disregard for the round religious buildings had also interesting consequences. As the use of the circle became noticeably inconvenient for the layout of churches, the oval, as the oblong version of the circle, began to consolidate its presence in church plan design. In fact, the oval option had already been present for architects and builders, as shown in Sebastiano Serlio's Il Primo Libro della Architettura, which included a lengthy discussion of the layout and geometry of the oval shape (Serlio 1545: fol. 13-20). Taking Serlio's treatise as a starting point, other texts continued to contribute to the spread of the oval geometry in the sixteenth and seventeenth centuries, some of which included recommendations and the techniques required for its lay out and construction (López Mozo 2011: 571-585).

Borromeo's recommendations also promoted other aspects of church design following Counter-Reformation doctrines, among them the aim to awe and surprise the viewer (Varriano 1990). Quoting Gianlorenzo Bernini's words, architecture's goal should be to "reach out with open arms to embrace Catholics in order to reaffirm their belief, heretics to be reunited with the Church, and agnostics to be enlightened with true faith" (Kitao 1974: 14). It is in this particular context, as the ideas of the Counter-Reformation spread along with the need for sacred spaces to take on a new role, that Guarino Guarini started his career. He advocated for an architecture widely based on sensorial experiences. However, geometric principles were at the core of this "architecture of sensations". It is not the aim of this paper to fully review Guarini's vast body of work and his outstanding geometric studies, but to discuss those of his works that set the basis for some of his geometric compositions and some of the constructive and structural innovations he produced that will later characterize the most important works of Central European Baroque architecture. 


\section{Guarino Guarini: Geometric Basis for Central European Baroque Architecture}

Guarino Guarini's typical layout in his church designs may be summed up as a clustering of correlative spatial cells along a given axis that the viewer perceives as successive expansions and contractions of one single space. This compositional principle, which Christian Norberg-Schulz called "pulsating juxtaposition", maintains the intent of spatial continuity as seen in Sant'Andrea or the Gesù, but enhances the stimulation of the viewer's senses (Norberg-Schulz 1985: 74). In order to shape these spatial cells in his compositions, Guarini needed a clearly identifiable geometrical pattern to become the basis for the plan's layout. The intention was for the viewer to identify each spatial cell within the given sequence. This is why the integration of the layout of each cell with the church's structural walls and vaults became fundamental. Hence, although for Guarini the plan was a primal compositional tool, it was not the only one he needed: the study of the section is also relevant to fulfill this integration between the floor plan, ceilings and walls.

In his first experiments Guarini employed the octagon as a plan unit for the spatial cells to generate his designs. Guarini's initial use of the octagon came about due to his interest in reinterpreting Gothic architecture and its ribbed vaults (Guarini 1737: Trat. III, lastra XIX). Specifically, the use of the octagon derived from the ribs of Gothic vaults to end in large piers. These piers, located at the vertexes of an initial square, were rotated $45^{\circ}$ in order to make it easier to receive the diagonal ribs. It is precisely this rotation that produces the chamfering of the vertexes, thereby shaping the octagon. The octagonal plan unit became a very suitable resource for Guarini's compositional needs. Its geometry allowed the implementation of a vault structure supported by four diagonal arches that rested on the vertexes of the octagon. The possibility of using a perfect circular outline for these arches facilitated their construction, as well as the construction of the severies between arches. In addition, this spatial cell, based on the geometry of the octagon, was versatile enough in order to comply with Guarini's different spatial compositions, since grouping and juxtaposing became particularly easy, as it can be seen in his proposal for San Filippo Neri in Turin (Guarini 1737: Trat. V, plate 14) and for St. Anne Royale in Paris (Guarini 1737: Trat. V, plate 9).

The simplest spatial cell within the octagonal pattern plan is the one inscribed within a square. This basic solution allowed solving the vault structure simply by using its ribs as circular arches whose centers are all contained in a same plane, typically the plane of the cornice. However, when this octagon was inscribed within a rectangle with the intention of providing the cell with certain axiality, while still keeping the proportion of the square pilasters and their $45^{\circ}$ rotation, a topological problem arose. In this case, not all diagonal arches had the same radius, and therefore did not meet at the keystone. This situation is shown in the proposal Guarino Guarini developed for San Filippo Neri, which would never be realized, as the architect Filippo Juvarra took over the commission to build the church following a completely different design (Gritella 1991).

In order to solve this geometrical problem, Guarini proposed for St. Anne Royale in Paris to split the diagonal rib into two parallel ribs, thereby achieving a vault 
surface based on spherical and cylindrical sectors while concentrating all issues related to geometrical incompatibility into a large irregular hexagonal boss at the keystone of the arches.

As an evolution of the research described above, and in his search for a more dynamic-looking plan, in later designs Guarini began distorting the sides of the octagon. One of the best examples of this new pattern can be found in his design for San Lorenzo in Turin, where he used an octagon with concave sides. However, in Guarini's designs this other type of octagon only appeared in central plan designs, since spaces of longitudinal clustering, which from a geometric point of view, were much harder to compose using this pattern (Fig. 1).

Guarini's next set of experiments with church layouts had entailed the use of oval units in his plan drawings. As explained above, the lengthening of the octagonal shape led to important geometric conflicts. If the centralized shape to be stretched out is a circle, the subsequent curves of reference become the ellipse and the oval. Of these two, the oval had the advantage of being better known, thanks to its presence in numerous treatises (López Mozo 2011). As such, it would become the geometrical form employed by Guarini. In fact, to Guarini, the oval pattern proved to be much more versatile than the oblong octagon, and it also provided fluidity in his intent of clustering spatial cells as "pulsating juxtapositions" (see Guarino Guarini's proposed plan for St. Maria di Ettinga in Prague, 1679; Guarini 1737, Trat. V, plate 19).

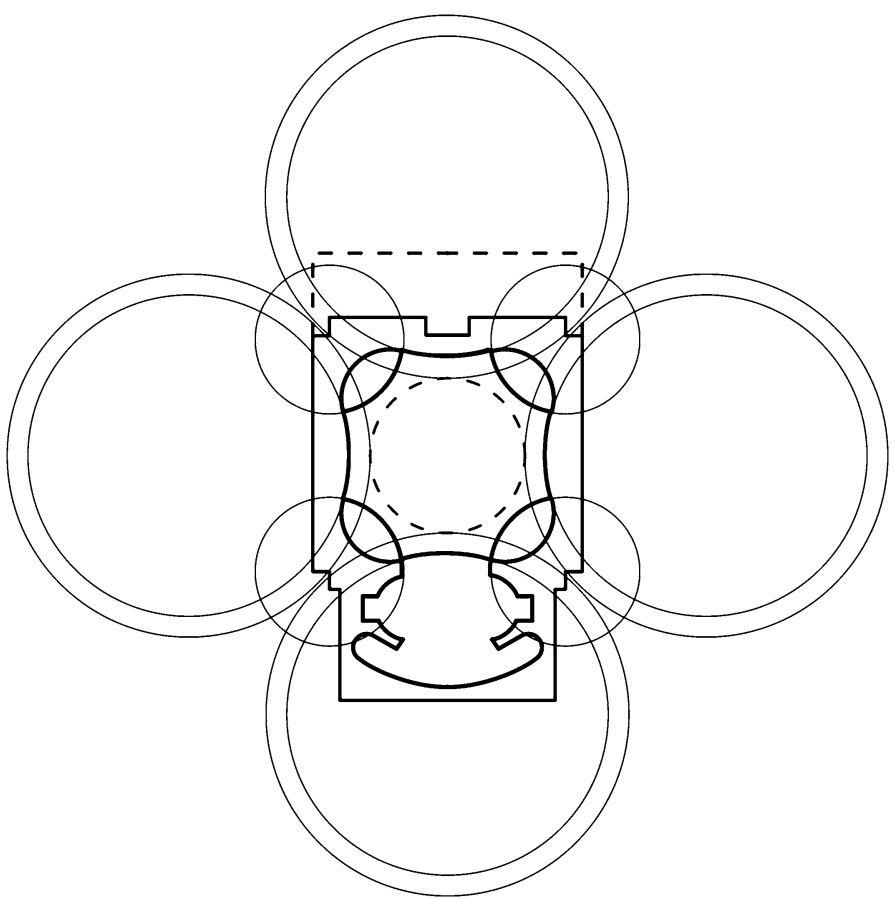

Fig. 1 Compositional diagram in plan for San Lorenzo in Turin, 1668-1687, according to Valderperren and Kennes. Image: authors, after Meek (1988: p. 46, plate 34) 
The oval was also preferred over the ellipse for geometrical reasons, mainly because the ellipse is difficult to integrate in compositions along with other geometric shapes, as it has a variable curvature. In general, the problem with the ellipse derives from the geometric properties of this curve, as simple operations such as setting a tangent to other elements-whether linear or not-become a problem. Meanwhile, the oval is made up of perfectly circular arcs and thus displays a constant curvature. This means that tangencies can be precise and are easy to layout. These specific properties of the oval form allowed more freedom when it came to design geometric floor plan compositions, a fact that would become very useful for architects. Even though some authors have proven the existence of elliptical layouts in architecture (Gentil Baldrich 1996), and considering the high degree of approximation of the ellipse to the oval (Rosin and Trucco 2005), elliptical shapes are rarely used when it comes to actual construction (Huerta 2007).

However, designing with oval patterns in drawings of plans translates into some inconveniences when it comes to working with the corresponding section. If the juxtaposition of units is addressed from a spatial point of view, it is necessary to point out how the vault surface is generated, whether the layout plan is oval or elliptical. In the case of the oval, the surface produced by rotating it around its major

Fig. 2 a The resulting surface of rotating an ellipse around its major axis (above), b The resulting surface of rotating an equilateral oval around its longer axis (below). Note that the orange curve describes the trajectory of one of the centers in such operation. Image: authors (color figure online)
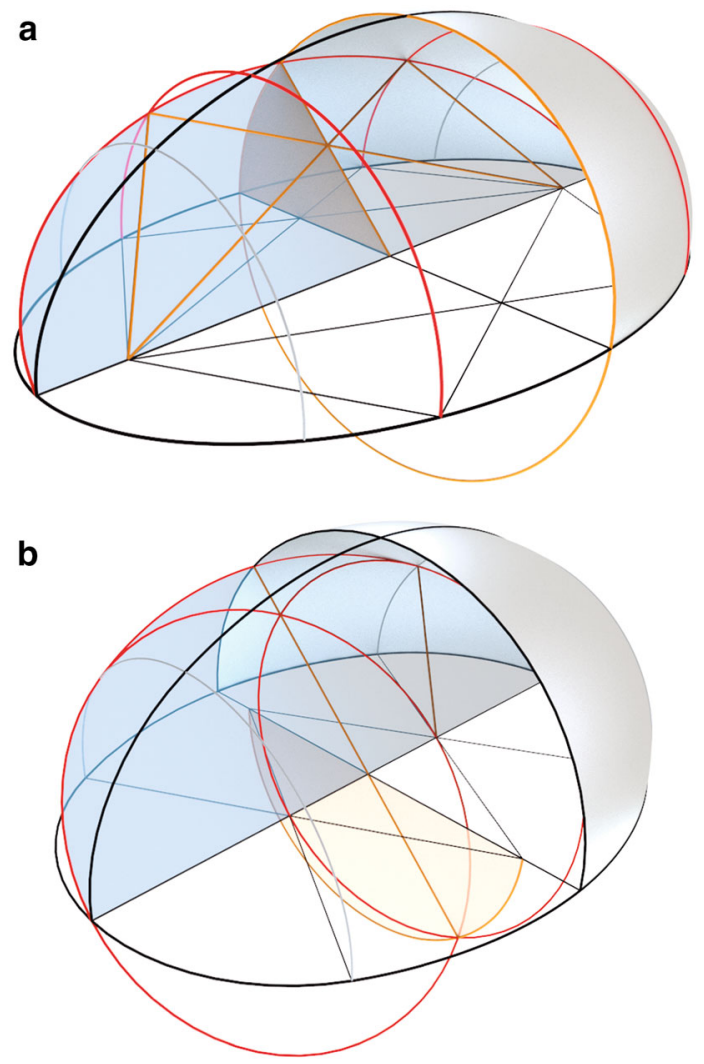
axis of symmetry is an ovoid. The resulting shape involves some difficulties when it comes to its construction, since some of its centers are not contained in the rotation axis (Fig. 2).

These difficulties resulted in a specific way of building oval vaults. Santiago Huerta describes how, historically, the construction of vaults over oval plans was carried out by placing a succession of brick or masonry rings without the use of scaffolding. In this case, some "guides" or guiding lines were more useful than establishing references to centers which were difficult to locate in space. As for the guiding lines, according to Huerta, those that were used the most during the construction process were the longitudinal and cross section lines of the vault (Huerta 2007: 237).

Baldassare Peruzzi, Sebastiano Serlio and Giacomo Vignola were the first to advocate the use of vaults over oval floor plans, and soon after other authors incorporated them into their designs (Huerta 2007: 230). However, Guarino Guarini was the first architect to experiment with the clustering of oval spaces, after the compositional experiments which grouped octagonal spatial cells mentioned above. Early on in 1656, Guarini proposed a composition based on the clustering of oval shapes for Santa Maria della Divina Providenza in Lisbon (Guarini 1737, Trat. V, plate 17). In this case, Guarini solved the structure over the oval cells by using predefined radial ribs, bosses at the keystones of the vaults and masonry shells that had been adapted to previously established guiding lines. As we can see, this solution is analogous to that proposed for the plan with octagonal cells inscribed within a rectangle for St. Anne Royale and St. Maria di Ettinga.

By the end of his career, Guarino Guarini had developed some compositions based on the grouping of ovals which later became essential to the development of Central European Baroque architecture. Specifically, his 1679 proposal for St. Maria de Ettinga in Prague should be highlighted. This design was based upon a longitudinal composition with three major parts. The two at each end were ovalshaped and laid out with their main axis perpendicular to the general plan's longitudinal axis. The central section was an octagon inscribed within a rectangle which was also laid out with its longer sides perpendicular to the general plan's longitudinal axis. In this case, Guarini once again solved the structure to cover the space over the ovals and the central octagon with the same kind of solution he used for the church of St. Anne in Lisbon; this is, radial ribs, bosses at the keystones and surfaces adapted to predefined guiding lines.

The second fundamental element for the further development of compositions based on the grouping of ovals in floor plan drawings are Guarini's studies on the intersections of quadric surfaces. His Trat. IV, lastra V (Guarini 1737) shows his study on the curves that result from the intersection of two cylinders whose axes of rotation meet perpendicularly. Guarini represents the resulting circumference when two cylinders with the same diameters intersect, as well as the warped curve that results when these diameters are different.

Guarino Guarini did not carry out any projects that included these sorts of intersections. However, the influence of these studies on the German architect Christoph Dientzenhofer, who would later design and build a considerable number of churches in the region of Bohemia, is notable. 
There is disagreement over whether or not Guarini visited Prague to follow up on the development of his proposal for St. Maria di Ettinga (Meek 1988: 127; Sandonnini 1888; Schmerber 1902: 287), but the link between architecture in Prague before the 1700s and Guarini's designs and ideas has been established by several art historians. Czech author Mojmir Horyna refers to the singular presence in Prague of Guarini's proposal for Maria di Ettinga as the key to the later development of Christoph Dientzenhofer's architecture. Horyna also supports the idea Guarini's influence in Bohemia by highlighting how well-known his Dissegni d'archittetura civile et ecclesiastica of 1686 was in the region. It was present not only at the Monastery of the Theatines Library in Prague, but also in other existing Bohemian libraries (Horyna 1998). On the other hand, Milada Vilímková (Vilínková and Bruker 1989) establishes another connection by pointing out Christoph Dientzenhofer's trip to Marseille; on his way he may have stopped in Turin and perhaps was able to visit some of Guarini's buildings. In any case, historians agree that Christoph Dientzenhofer's architecture underwent an important shift shortly after Guarini's proposal for Sta. Maria di Ettinga was known throughout Prague.

\section{Bohemiam Baroque Architecture. The Dientzenhofer Family}

Influenced by Guarini's later works, Christoph Dientzenhofer soon preferred to outline his churches as one single space shaped by the clustering of interconnected spatial cells. Dientzenhofer, however, made these types of compositions evolve towards greater spatial fluidity. In Guarini's work, there was a juxtaposition of cells, all of which could be also recognized as individual entities. In Dientzenhofer's work spatial cells were linked together, one spatial cell overlapping the next. In this regard, he is considered to be the precursor of a Baroque principle that NorbergSchulz called spatial "syncopation" (Norberg-Schulz 1985: 96). The architecture of Dientzenhofer increasingly detached itself from the recognizable geometries inherited from Renaissance architecture (which were still present in Guarini's groupings of spatial cells), and moved towards a more faithful fulfillment of the Counter-Reformation aspirations for Catholic temples: a single longitudinal fluid space whose geometry becomes elusive and reveals endless surprises and unexpected effects to an over-awed viewer.

In Dientzenhofer's designs the oval shape takes on the leading role of the composition. However, as with other architects who built vaults over oval layouts, in order to define the covering structure of his buildings he did not use the geometry of the surface that resulted from rotating the floor plan oval around a rotation axis. Dientzenhofer's alternative was to build these vaults following certain structural ribs that had been laid out as a basic skeleton or structural framework for the structure. These ribs had a geometry he could control and followed the layout of the floor plan and the elevations. Once the ribs were in place, he would fill the space between them with a surface that easily accommodated itself to these ribs. Due to this particular way of building, Dientzenhofer concentrated his efforts into making the geometry of the ribs as clear as possible, in order to reduce potential difficulties 
during their construction. This search for clarity, however, did not prevent him from designing structural ribs of unprecedented geometry in the history of construction. These ribs would become one of the characteristic features of his best designs. Specifically, in order to adequately define the ribs, Dientzenhofer incorporated the warped curve that Guarini had described in his study of the intersection of two perpendicular cylinders of different diameters. Dientzenhofer used this geometry to interconnect the cells at the level of the vaults, while freeing the actual surfaces of the ribs themselves. To outline this warped rib, the generatrix of the vertical cylinder coincided with one of the arcs of the floor plan's ovals, while the horizontal cylinder was considered a virtual barrel vault (Figs. 3, 4, 5).

In general, in the work that Christoph Dientzenhofer developed at the beginning of the seventeenth century and after, the influence of Guarini is clear (Vilímková and Brucker 1989; Franz 1942). In addition to experimenting with the ovals and the warped ribs that derived from Guarini's geometric studies, Dientzenhofer worked with the concave-sided octagon that Guarini had also tried out in some of his compositions (Fig. 6).
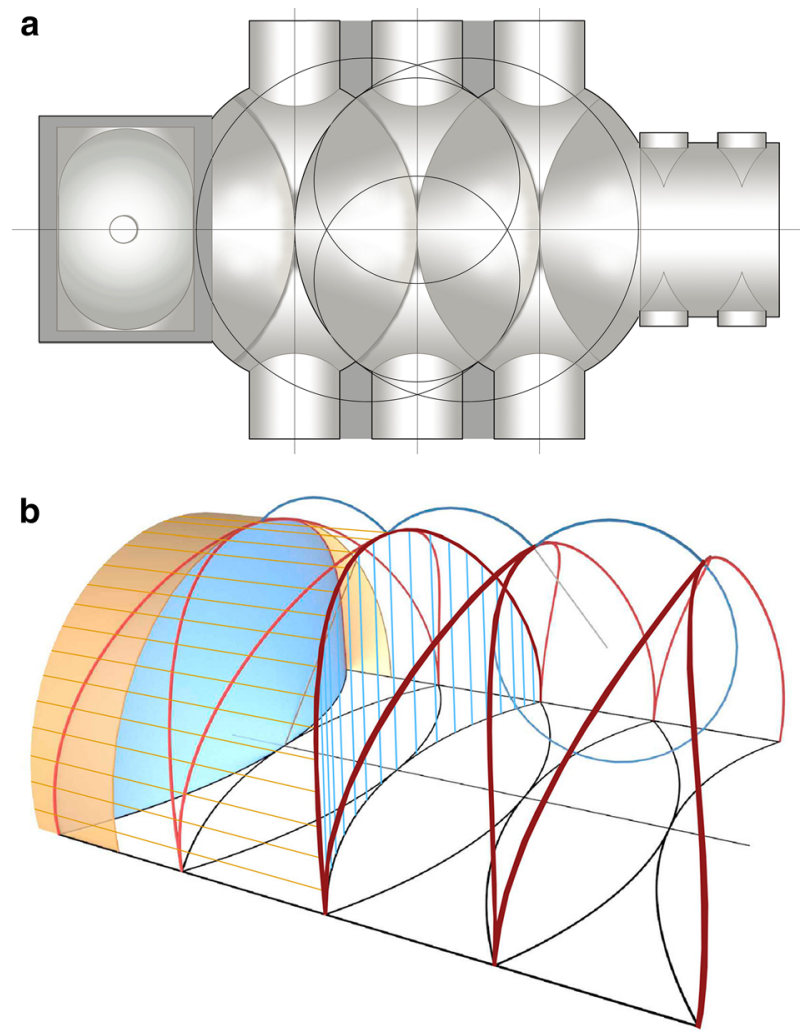

Fig. 3 Christoph Dientzenhofer, drawing in plan of the vaults of the proposal for S. Nicholas church in Mala Strana, Prague, 1703. Image: authors, after Vilímková and Brucker (1989: p. 93). Diagram showing how the layout of its warped ribs is generated. Even though they were never actually carried out as planned, this was the first design by Christoph Dientzenhofer's that included warped ribs 

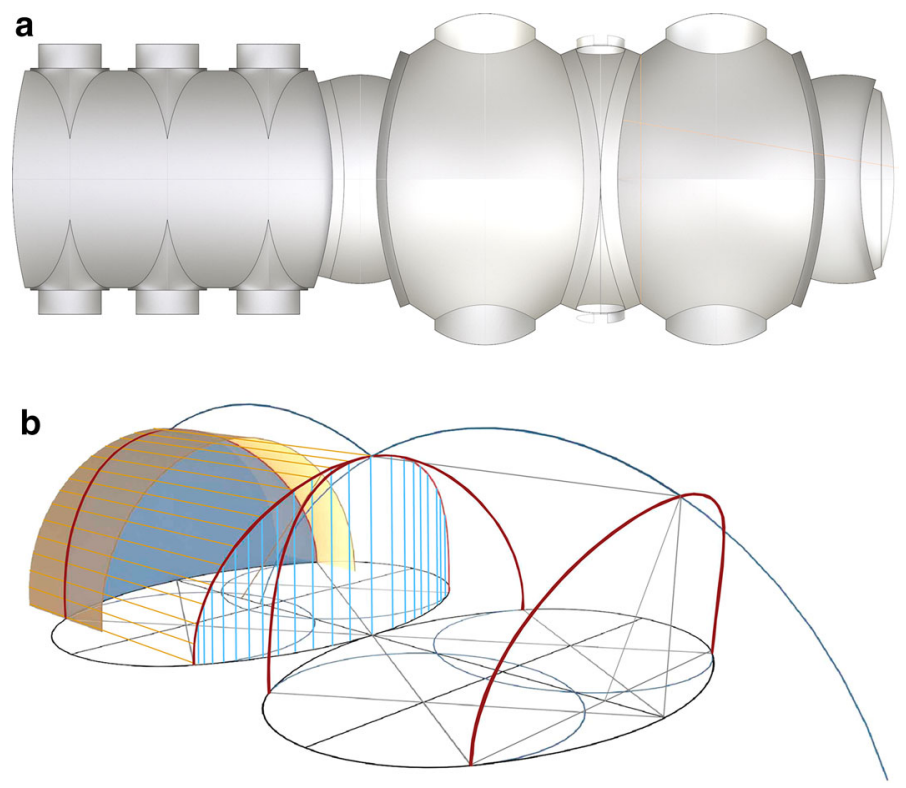

Fig. 4 Christoph Dientzenhofer, drawing in plan of the vaults of St. Klara church in Eger, 1708. Image: authors, after Freiherr von Ritter zu Groenestein Archive (archive, Kiedriel). Diagram showing how the layout of its warped ribs is generated

Dientzenhofer's warped ribs represent a stunning compositional and technological tour de force, especially considering that these vaults were built with a single layer of brickwork. The ingenuity of the solution depended on how easily the curve could be outlined in space prior to its construction. Since the warped curve is defined by circular circumference-based surfaces, the operation's feasibility was guaranteed.

However, it was not always that easy for architects to represent this new element in their two-dimensional drawings, something that lead to many erroneous representations of the warped ribs in buildings' cross section drawings. The difference is obvious if we compare the original cross section drawn for San Nicolas in Mala Strana, Prague - the design for which Dientzenhofer proposed the warped rib for the first time-and the correct projection of this warped rib (Fig. 7).

Monotony is definitely not a feature of Christoph Dientzenhofer's church designs, even though it is true that, after his work for S. Nicholas, in the designs that followed, he continued to reprise a series of the same themes: elongated spaces; sequences of ovals arranged with their longer axis perpendicular to the main axis of the church, and warped ribs where the ovals shown in the floor plan intersect at vault level. However, he also experimented with the different distances between the ovals, an exercise that generated very different vault surfaces and spaces.

The main elements for the design of the vaults in S. Nicholas in Mala Strana, 1703, St. Klara in Eger, 1708 and St. Margaret in Břevnov, 1709 are described in Figs. 3, 4 and 5. In S. Nicholas, where the ovals are displayed in the floor plan in 

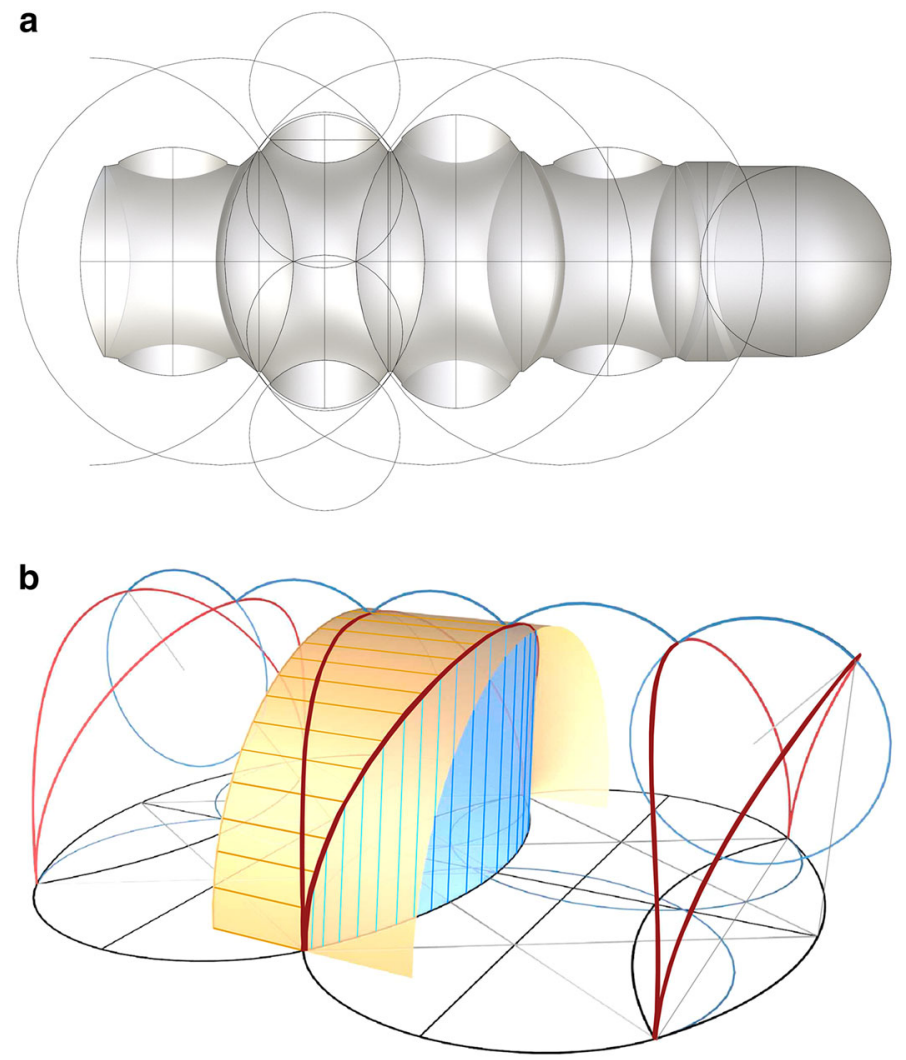

Fig. 5 Christoph Dientzenhofer, drawing in plan of the vaults of St. Margaret chapel for the Břevnov Abbey, Prague, 1709. Image: authors, after Franz (1985: p. 65). Diagram showing how the layout of its warped ribs is generated

such a way that the center of one oval coincides with the end of the minor axis of the next, the resulting space has more uniformity than in St. Klara or St. Margaret, where expanded and compressed spaces are alternated. In St. Klara, this is achieved by maintaining the two main ovals tangent to each other. Meanwhile, in the composition for St. Margaret, the major axes of the main ovals get closer together until the points of tangency of each oval match up. In these designs, the shapes of the floor plan composition influence how the vertical elements (walls and pilaster) are defined, as well as their relation with what happens at vault level. As such, the plan view of a warped rib coincides completely with one of the oval's arcs, from beginning to end, facilitating the rib's layout and thus its construction.

Christoph Dientzenhofer's designs influenced the work of architects that followed, who continued experimenting with spatial sequences and similar ideas, using warped ribs to merge cells. Within the Dientzenhofer family, the most relevant examples were produced by his brother, Johann Dientzenhofer, and his son Kilian Ignaz Dientzenhofer. Johann's most impressive work was carried out in the Banz Abbey, in 1710 (Fig. 8). 


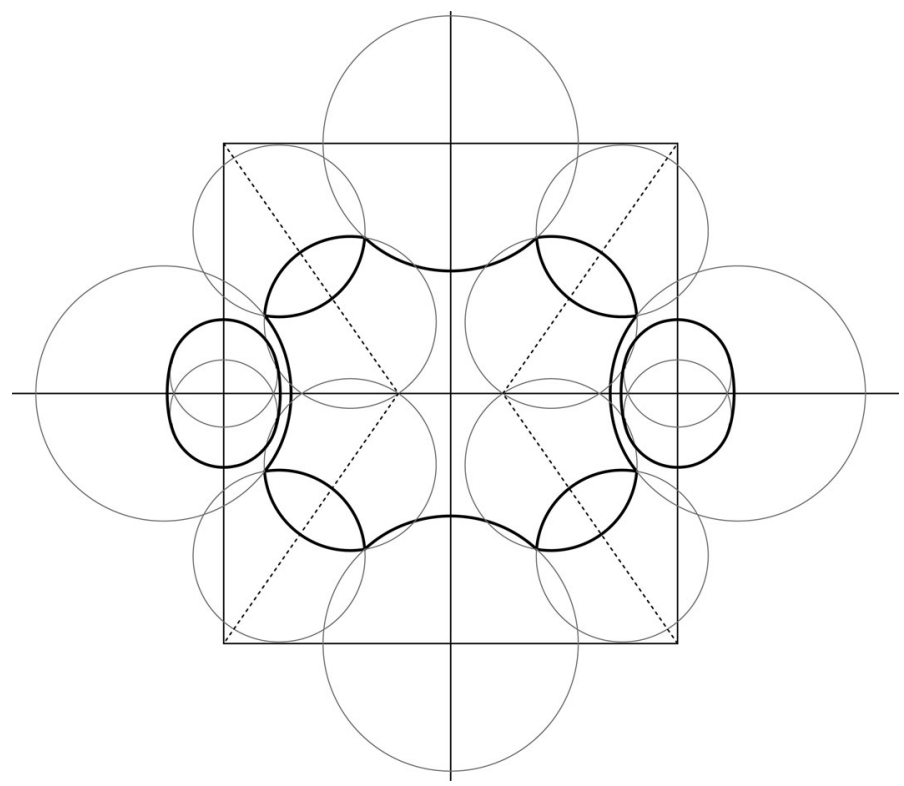

Fig. 6 Christoph Dientzenhofer, compositional diagram in plan for Smiřice Palace Chapel, 1706. Here Dientzenhofer adopts the concave octagon sides of Guarini, combined with ovals and minor warped ribs. Image: authors, after Meek (1988: p. 167)

There he achieved a structure with a longer span than what we have seen in the previous examples (the major axes of the main ovals built by Christoph were around $8 \mathrm{~m}$ long, while Johann's in Banz reached a length of $14 \mathrm{~m}$ ). Johann transformed the warped rib, which until then had been an eminently compositional resource, into an ambitious structural element. The geometric layout of these ribs, as the intersection of two perpendicular cylinders of different diameters, is similar to that used by Christoph, as the authors of this present paper were able to measure on site, and also consistent with the survey conducted by Alexander Wiesneth (2011).

Making the warped rib such an important structural element entailed the risk of subjecting them to added torque stresses. However, it is important to underline that in the cases analysed, the architectural techniques and compositions work together to minimize this effect. In the case of Banz Abbey, for instance, Johann Dientzenhofer lays out pairs of ribs that work as two arches that lean upon each other where their keystones meet. Given the span of the vault structure, and the larger surface that need to be supported, the structural performance of these pairs of ribs-which work collaboratively, in combination with the inverted "V" shapes in the keystones-helped stabilize the system three-dimensionally, counterbalancing horizontal stresses (Figs. 8, 9). In addition, brick ribs were built by bonding them into the vaults (Wiesneth 2011), confining them so that the torque stresses that resulted from the design of the warped element were reduced to a minimum.

Through his work, Kilian Ignaz Dientzenhofer, showed an interest in other compositional possibilities. His churches are predominantly central in character, but 
a

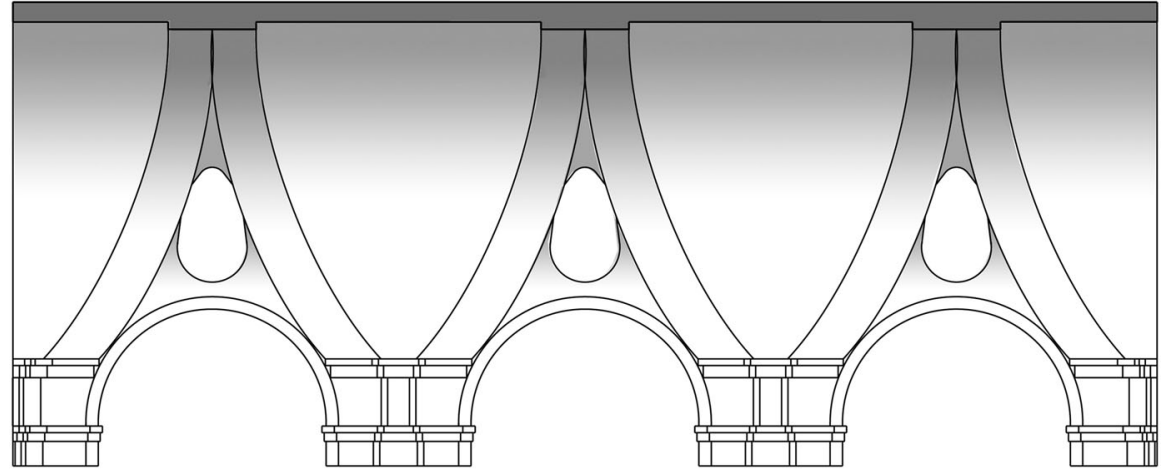

b

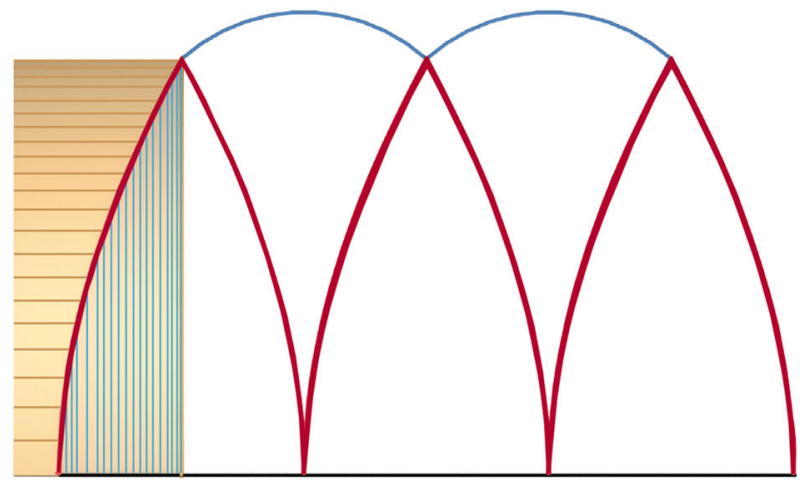

Fig. 7 Christoph Dientzenhofer, S. Nicolas in Mala Strana, 1703. a Original drawing of warped ribs (above). Image: authors, after Vilímková and Brucker (1989: p. 91), b diagram showing the correct projection of these warped ribs (below)

this centrality is combined, through skilful layouts, with a series of formal elements that reinforce the main longitudinal axis. In general, these buildings are of a reduced scale with more manageable dimensions. In these designs he included the distinctive warped ribs that his father and uncle had used. However, he did not require them to play the important structural role that Johann had assigned them. Furthermore, there is another relevant difference between the way Kilian Ignaz used the warped ribs and the way Christoph and Johann did. For the latter, the rib was a fundamental element to achieve "spatial syncopation". In Kilian Ignaz's compositions, however, the joining up of the ribs juxtaposed spaces, thus his designs were closer to the legacy of Guarino Guarini's works than to those of his immediate predecessors (Fig. 10).

\section{Balthasar Neumann in Germany. Geometry and Technology}

Beyond the Dientzenhofer family, Balthasar Neumann, widely considered to be one of the most brilliant architects of Central European Baroque architecture, is the most 

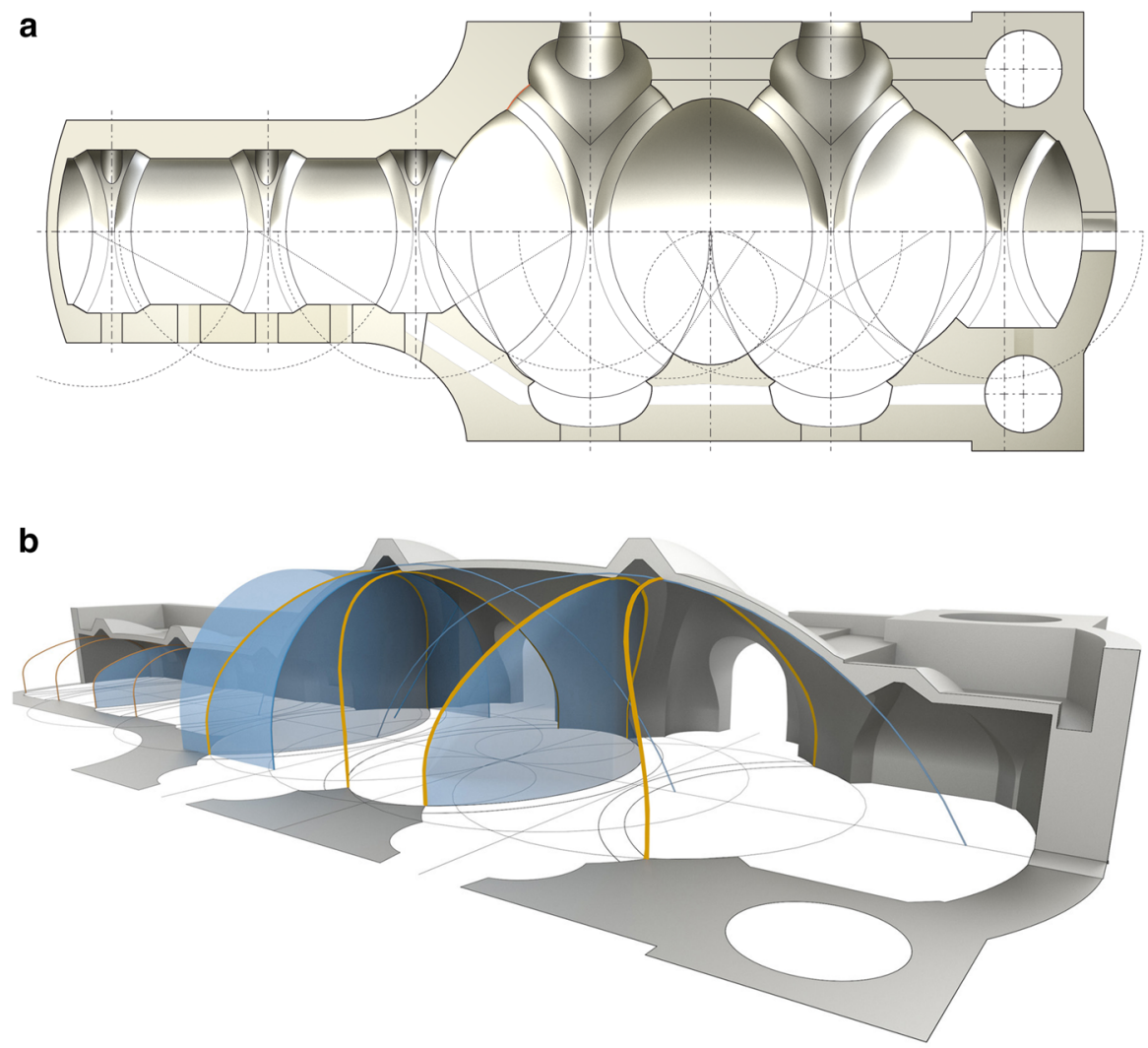

Fig. 8 Johann Dientzenhofer, Banz Abbey, 1710. Generation of the design of the warped ribs that organize the roof structure

relevant figure in the further development of the ideas discussed in this paper. The influence that the Dientzenhofers had on Neumann has been well documented, beginning with the contact he made with Johann during the construction of the Würzburg Residenz (Otto 1979). As a result of this contact, Neumann began to incorporate the blending of spatial cells and the use of warped ribs as features of his architecture. In order to produce further unexpected effects and surprises, Neumann's compositions were more ambiguous in their display that any of the previous examples. The search for powerful contrasts, typical of Baroque architecture (chiaroscuro, convex-concave rhythms, etc.), is surpassed in Neumann's work with the spatial display of interesting paradoxical dualities (longitudinality and centrality, unity and fragmentation). Thus, for instance, while Neumann's spaces unfold along a strong longitudinal axis, as required for the Tridentine liturgy, they also showcase an intense sense of centrality. For that purpose, in his compositions Neumann employs principles that do not differ much from the Dientzenhofers' "spatial syncopation". However, his main spatial units show an interesting independence from the whole. In particular, these main units 

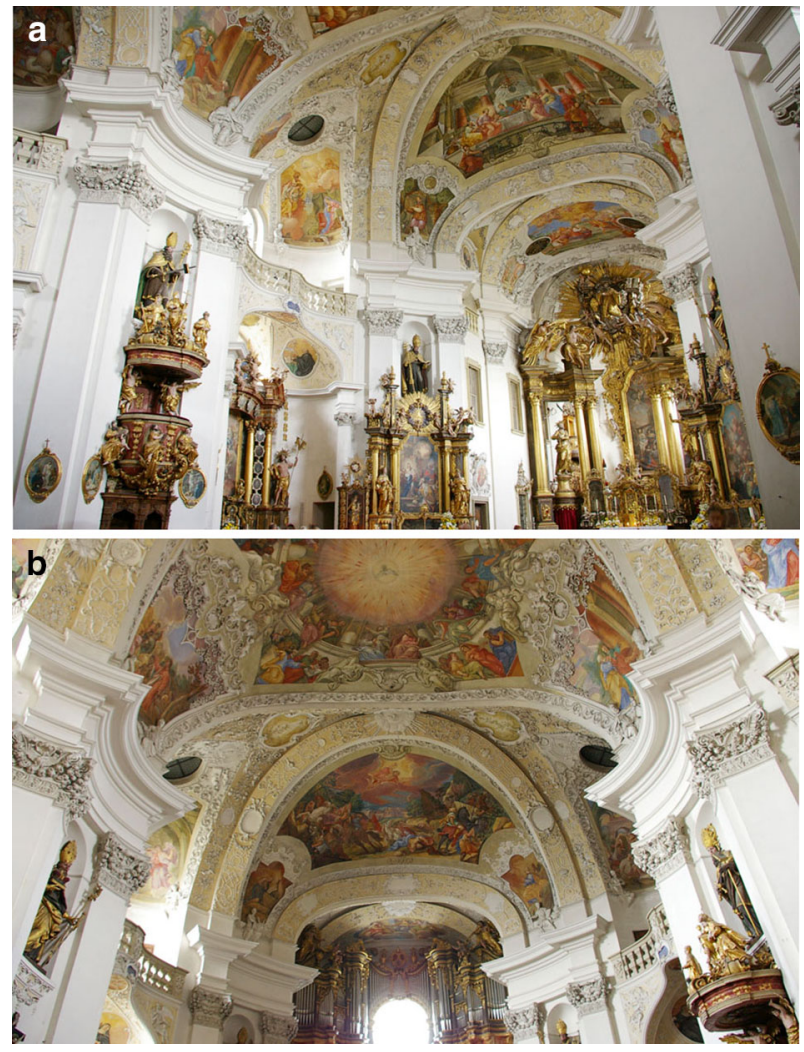

Fig. 9 Johann Dientzenhofer, Banz Abbey, 1710. Interior images of warped ribs. Note how the setback of the severies and the use of different colors highlight the presence of the ribs, showcasing their structural performance without any misgivings. Photos: authors

define a primary spatial cell that encloses a larger volume than those of the other units. This reinforced the independence of the primary spatial cell, as well as its centrality in relation to the surrounding cells, while maintaining a sense of unity of the whole by embracing the secondary cells, a technique that is reinforced by the exuberant display of large-scale ceiling frescoes (Figs. 11, 12).

The designs by Balthasar Neumann are more flexible than those developed by the Dientzenhofers. On the one hand, Neumann did not exclusively use equilateral ovals, and on the other, he was open to the inclusion, in the same composition, of ovals that were completely different in proportion and dimension. Nevertheless, this flexibility does not imply arbitrariness. Neumann's background-he was an artillery engineer for the army (Otto 1979: 28)—left no room for fortuity. Further, it should not be forgotten that these designs had to be laid out to scale during the building process, therefore these seemingly capricious compositions normally relate to an order based on simple, although not clearly evident, operations.

To investigate the influence of transformational geometry and high mathematics in the development of Baroque architecture, we have attempted to recreate the 


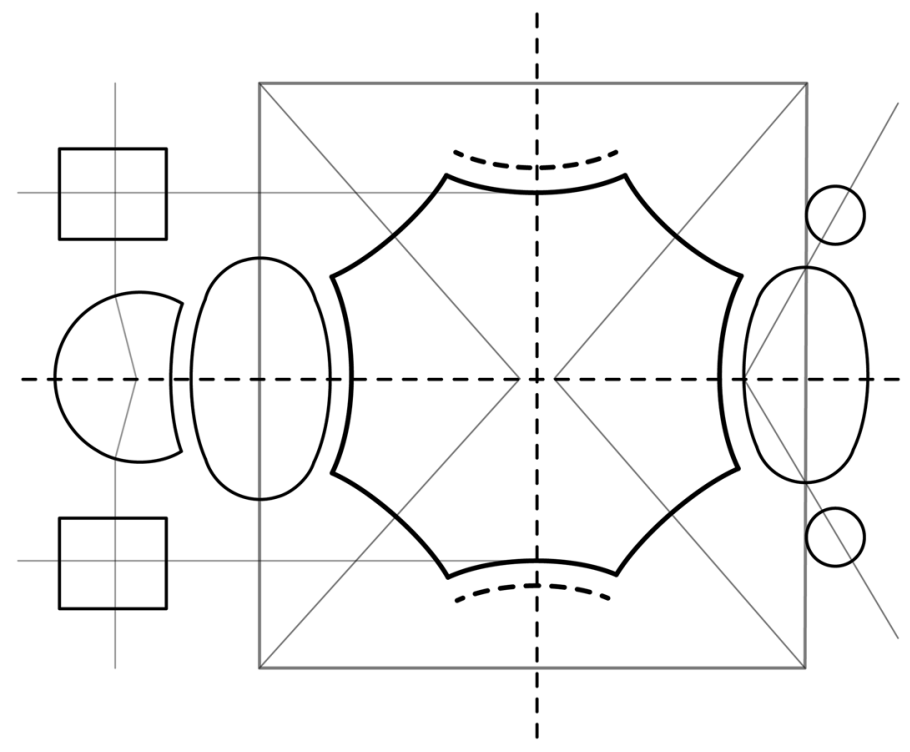

Fig. 10 St. Johann Nepomuk, 1730, considered by many as one of Kilian Ignaz Dientzenhofers the major works and one of the most distinctive buildings of Bohemian Baroque architecture. A strong centrality is provided by the use of the octagon and strengthened by the two diagonal axes that derive from it. Independent oval cells are juxtaposed to the central one through the use of the warped rib. Image: authors, after Norberg-Schulz (1993: p. 188)

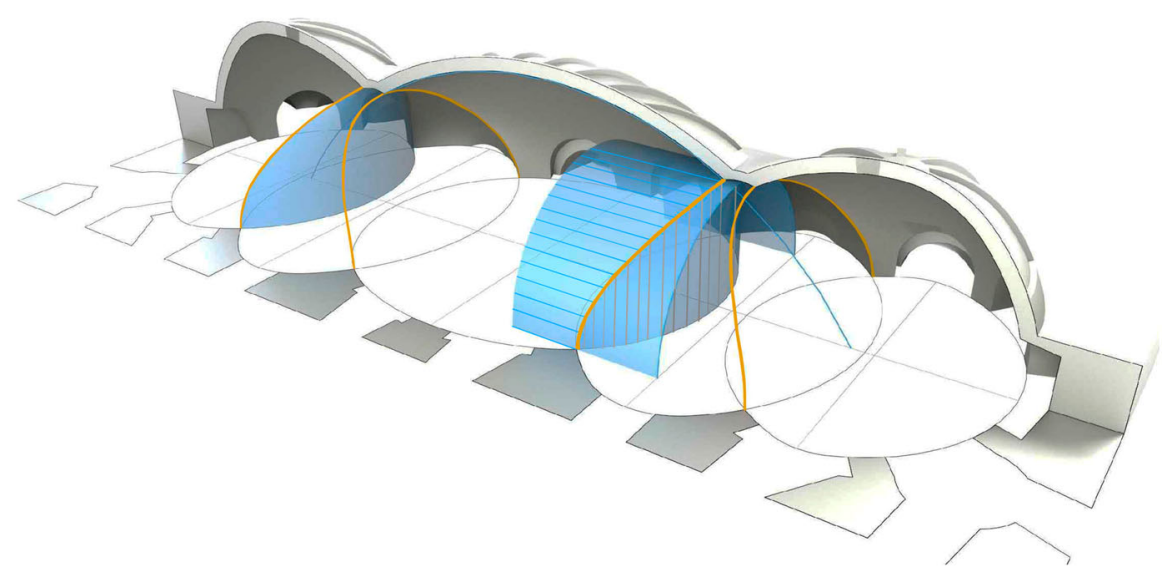

Fig. 11 Balthasar Neumann, Würzburg Residence Chapel, 1719. Outline of the plan view composition and diagram showing how the layout of its warped ribs is generated. Note the greater dimensions of the central oval and its arrangement. While all the ovals that integrate the design have their major axes perpendicular to the spatial sequence, the central oval is laid out with its major axis parallel to this sequence. Image: authors

geometric operations that Neumann used for the layout of the Wurzburg Residence Chapel (Fig. 13). As shown, these are basic operations within plane geometry, something that supports the serious doubts that have been raised in relation to the 


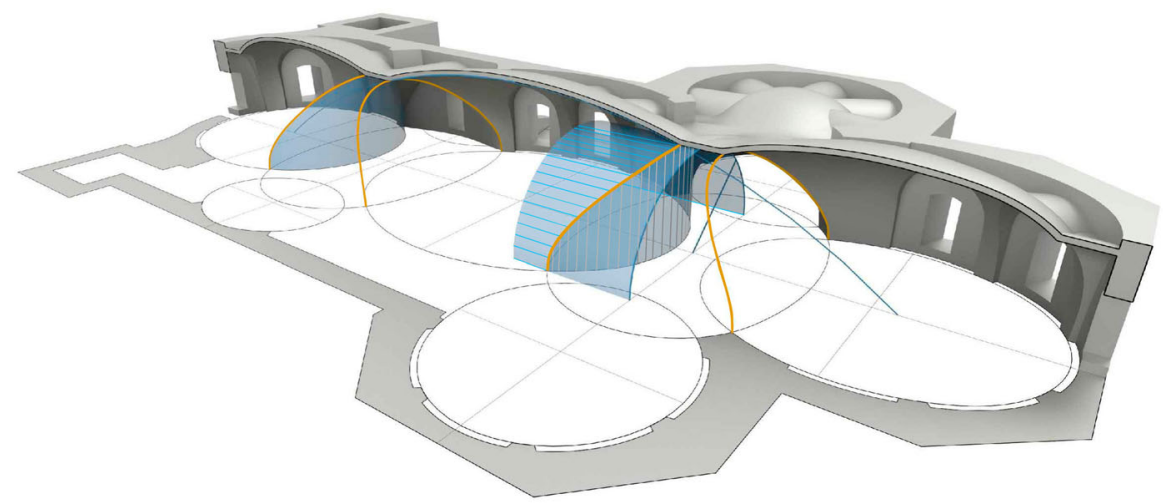

Fig. 12 Balthasar Neumann, Basilica of Vierzehnheiligen, 1743. Outline of the plan composition and diagram showing how the layout of its warped ribs is generated. Once again, in the design a central nature can be observed. In this basilica, the central oval is not only larger than the others, it is also separated from the perimeter wall. Norberg-Schulz called this is a way of shaping spaces "dominant central rotundas" (Norberg-Schulz 1985: 74). Image: authors

advanced mathematical knowledge of authors such as the Dientzenhofers or Neumann (Clagett 2014; Caparrini and Speiser 2004).

There is another aspect in Neumann's work deriving from the compositional operations described above that make his designs with ovals more flexible than those carried out by the Dientzenhofers. The latter laid out the oval plan cells with their major axes parallel to each other, forcing the ovals' tangency points to coincide so that the warped rib, in plan view, could correspond to a full circular arc of one of the ovals also in floor plan view. This assumption limited compositional possibilities, so Neumann avoided it by including new approaches related to changes in the layout, the dimensions and the proportions of the ovals in the floor plans, as explained above. At both the Würzburg Residenz chapel and the Neresheim convent, the vertical cylinder which is involved in the generation of the warped rib is defined by a single circular arc, but it is not one of the complete arcs that shapes the corresponding oval. Meanwhile, at the Vierzehnheiligen basilica, Neumann employs warped ribs whose plan projection is a curve defined by arcs belonging to three different circles, which was nevertheless still easy to outline for construction purposes.

As for the representation of warped ribs, and as mentioned regarding Christoph Dientzenhofer's drawings, Neumann also drew them incorrectly in his cross section drawings, where they appear as projections that include inflexion points (Fig. 14).

It is also important to remark that Neumann used warped ribs as a mere compositional tool. The geometric principle of the rib is analogous to that proposed by the Dientzenhofers, with the difference that for Neumann these ribs were not part of a main structural framework that supported the surface between them. Unlike the Dientzenhofers, Neumann conceived his vault structures as continuous surfaces, so that the warped curve would not become an element in itself, but was conceived as the intersection between two surfaces without any reinforcement. In fact, in order to 


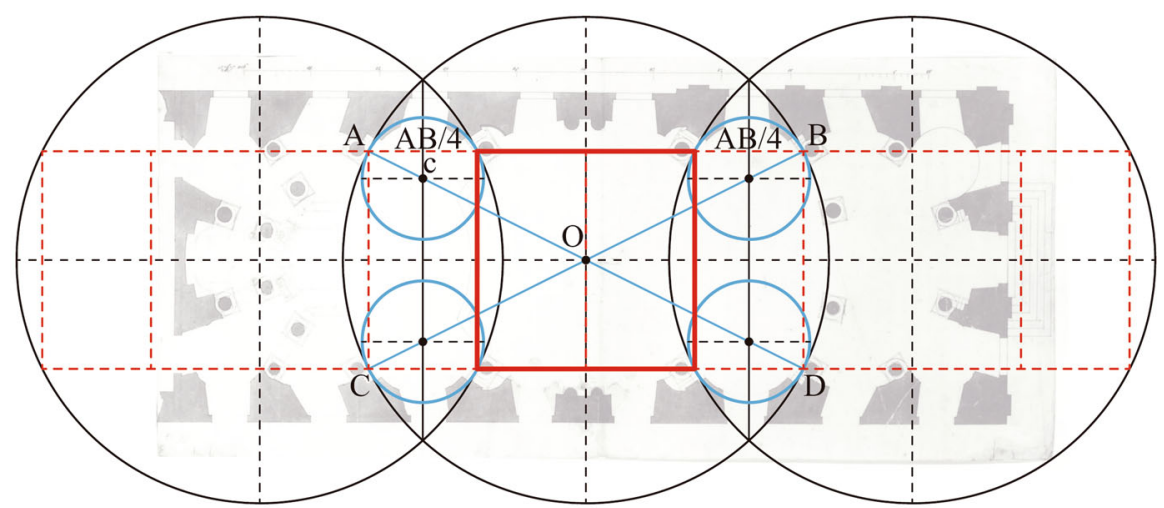

1)

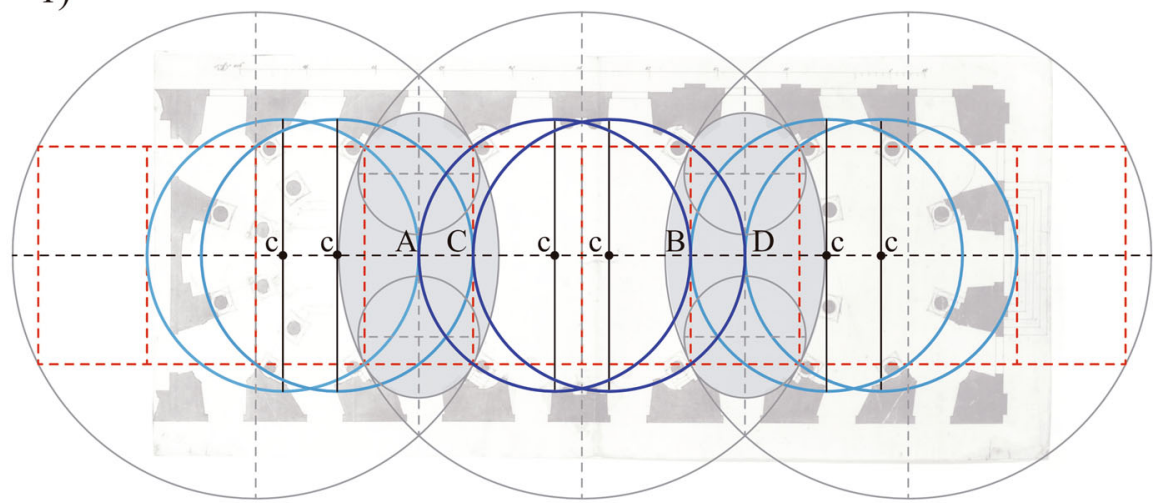

2)

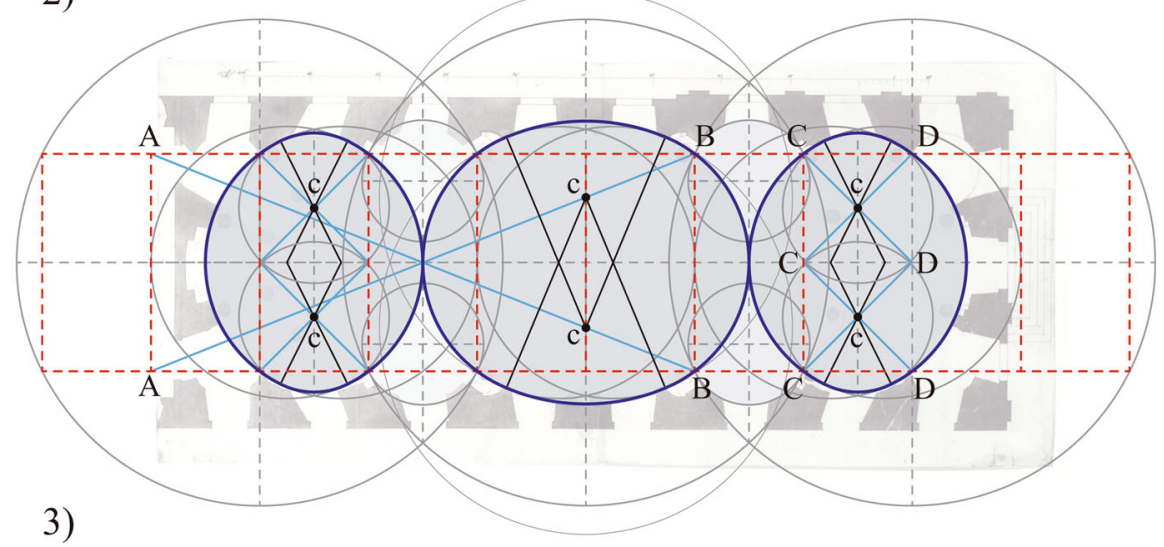

Fig. 13 Würzburg Residence Chapel. Geometric operations in the generation of the layout. Proposal based on a facsimile reproduction of the original plan, which shows key points through marks and signs that drawing instruments left on the paper. 1 Central rectangle with a proportion of 2:1 inscribed within a circular circumference. Left and right displacements of both elements, defining overlapping rectangles of a quarter of their largest dimension (AB/4). Definition of intermediate ovals, 2 circular circumferences, whose centers correspond to those of the oval in the main spatial unit, $\mathbf{3}$ definition of the main and remaining lateral ovals' centers. Image: authors 

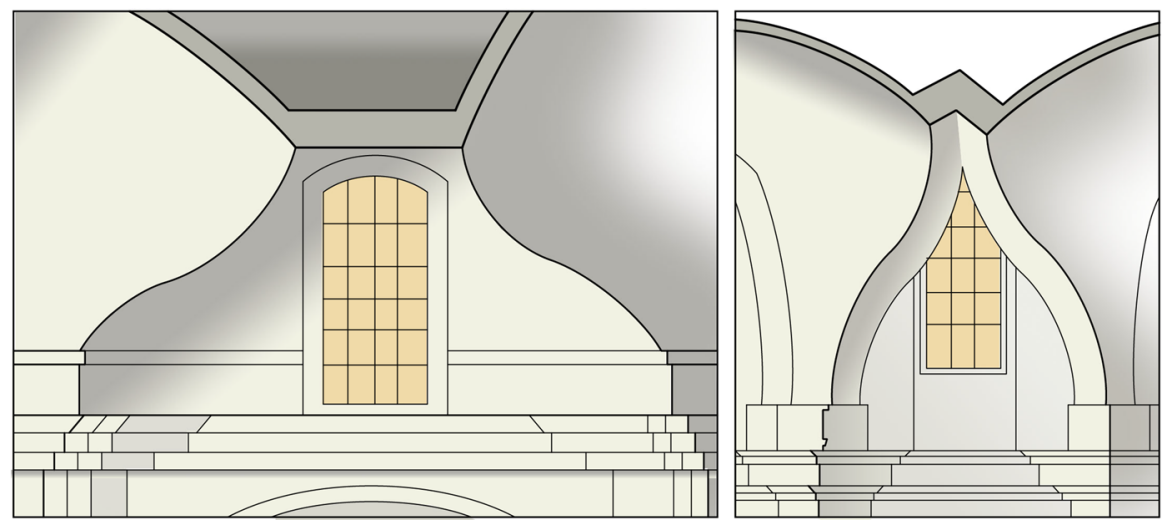

Fig. 14 Balthasar Neumann's projections for warped ribs. a Basilica of Vierzehnheligen (left). Image: authors, after Eckert Collection: SE-0.86 (Mainfränkisches Museum, Würzburg), b Benedictine Convent of Neresheim (right). Image: authors, after Eckert Collection: SE-120 (Mainfränkisches Museum, Würzburg)

highlight the existence of these intersections, on the inside surfaces Neumann added a layer of plaster with a different color to emphasize their presence as warped ribs so, in his buildings, the interior spaces do not reveal the true nature their structural performance (Fig. 15).

Thus, the structural behavior of Neumann's vaults is closer to that of a structural membrane (Compán 2012) that employs a double curvature geometry in order to guarantee the general stability of the structure. In contrast to the Dientzenhofers, Neumann did not consider the warped curve as an independent structural element, but as an integral part of the vault's structural system.

\section{Conclusion}

Compositional innovations in Central European Baroque architecture sought to challenge conventional spatial relations in order to awe the viewer. But behind this intense dramatization of the spatial experience, there was amazing ingenuity and research in order to outline the complex geometries and the specific spatial compositions that would make this architecture possible. The strong geometric principles that lay behind the construction of these buildings leads us to think that a probable reference for this architecture is the work of the architect Guarino Guarini, who was also a mathematician.

Guarino Guarini was the first to describe intersections of quadric surfaces in order to address aspects directly associated with their building process, but he never carried them out. His compositional innovations, which were based on the clustering of spatial cells of oval-shaped layouts, would become a source of inspiration for following generations, although his ribbed vaults still displayed traditional flat arches. Only after the Dientzenhofers and Neumann realized their designs were these intersections of quadric surfaces built for the first time. Taking into account 

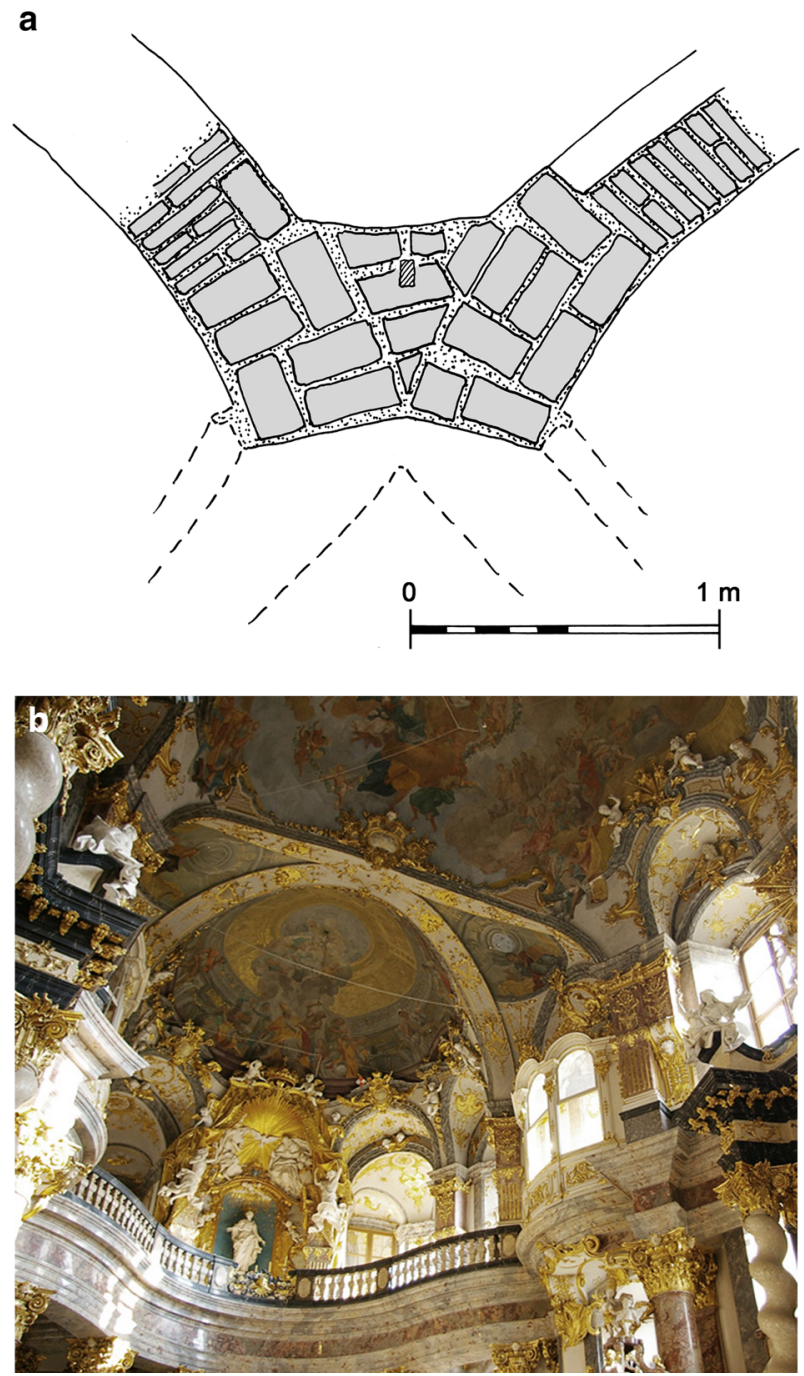

Fig. 15 a Section showing the layout of the brickwork at the warped intersection between surfaces (Wiesneth 2011) (above), b image showing the different resources used to highlight as a rib the warped intersection (below). Photo: authors

the challenges they faced and given the technology available at the time, this is quite a feat. This article shows how the construction of these complex surfaces involved the use of warped ribs, which would later become features of the Dientzenhofers' and Neumann's designs, contributing greatly to the history of construction in Central European Baroque architecture.

It is also interesting to observe how the Dientzenhofers and Neumann developed these innovations in very different ways, something that probably relates to their 
disparate backgrounds. The Dientzenhofers were a family of great builders, and as such, they faced these challenges by following the paths that their practical experience had given them: they first outlined the warped ribs as a framework and as basic structure for building the vaults. By doing this they facilitated the construction process. As a result, Dientzenhofers' vaults had entirely smooth surfaces, because their ribs were located solely where the different spatial cells met. However, Neumann, who was trained as an artillery engineer in the army, had a different approach: he conceived the vault as one single structural system, in which the warped ribs were only part of the visual display of the composition where the different surfaces met.

Baroque architecture has often been regarded as an art of illusory and decadent plaster and gold leaf fanfare, but the work of the Dientzenhofers and Neumann shows how unprecedented structural and construction innovations were harnessed in order to comply with the challenges posed by the spirit of the CounterReformation. Architecture historians have traditionally stressed Baroque architecture's use of spectacular displays, tricks and illusions. Descriptions, for instance, of Neumann's work emphasize his "seemingly infinite luminous spaces" (Norberg-Schulz 1985: 74), or how "color and luminosity burst forth ...; piers vanish into the decorated planes of the ceiling ...; light floods in and color snatches the eye" (Smith 1990: 114). In general, statements about Baroque architecture insist on the idea of effect and mention some of the concepts behind their compositional motifs but they barely address the technical knowledge that made it possible. Baroque architecture's alleged lack of structural clarity never quite fit in with the Dientzenhofers or Neumann's designs. In their projects, structural clarity is manifested in the different ways of ribbing their vault structures. Not until the end of the nineteenth century, with the works, for instance, of the Gustavino family and Antonio Gaudi, would experiments in brickwork membrane structures be found that are comparable in importance to those of Neumann. Even then, their origins are quite different, because Neumann's innovations were practically forgotten for centuries. The new ideas that the Enlightenment brought about consigned to oblivion one of the most intriguing technological chapters of architecture history.

Acknowledgments The authors wish to express their thanks to all churches that allowed their site survey, especially to Banz Abbey, Würzburg Residence Chapel and Basilica of Vierzehnheiligen, to the Institute for Design and Construction, University of Stuttgart, and to Alexander Wiesneth.

\section{References}

Blunt, Anthony. 1962. Artistic Theory in Italy, 1450-1600. London and New York: Oxford University Press.

Caparrini, S., D. Speiser. 2004. How Should We Study the Nexus of Architecture and Mathematics. Nexus Network Journal-vol. 6, NO. 2:7-12.

Clagett, John. 2014. Transformational Geometry and the Central European Baroque Church. In: Architecture and Mathematics from Antiquity to the Future, Kim Williams and Michael J. Ostwald, eds. Basel: Birkhäuser, vol. II, pp. 231-242. 
Compán, Víctor. 2012. Comportamiento estructural de las geometrías arquitectónicas del Barroco Centroeuropeo. PhD. Universidad de Sevilla.

Evans, Robin. 1995. The Projective Cast: Architecture and its Three Geometries. Cambridge, MA and London: MIT Press.

Franz, Heinrich Gerhard. 1942. Die Kirchenbauten des Christoph Dientzenhofer. Brünn, R. M Rohrer.

Franz, Heinrich Gerhard. 1985. Dientzenhofer und "Hausstätter". Zürich: Verlag Schnell \& Steiner München.

Gentil Baldrich, José María. 1996. La traza oval y la sala capitular de la catedral de Sevilla. Una aproximación geométrica. pp. 77-147 in Quatro edificios sevillanos. J. A. Ruiz de la Rosa et al., eds. Seville: Colegio Oficial de Arquitectos de Andalucía, Demarc. Occidental.

Gritella, Gianfranco. 1991. Juvarra: 1'architettura. Modena: Franco Cosimo Panini.

Guarini, Guarino. 1737. Architettura Civile del Padre Guarino Guarini. Torino: Gianfrancesco Mairesse all'Insegna di Santa Teresa di Gesù.

Horyna, M., Jaroslav, K. 1998. Dientzenhoferové. Prague: Akropolis.

Huerta, Santiago. 2007. Oval Domes: History, Geometry and Mechanics. Nexus Network Journal 9, 2: 211-248. doi:10.1007/S00004-006-0040-3.

Kitao, Timothy K. 1974. Circle and oval in the Square of Saint Peteŕs: Berninís Art of Planning. New York: New York University Press.

López Mozo, Ana. 2011. Ovals for Any Given Proportion in Architecture: A Layout Possibly known in the Sixteenth Century. Nexus Network Journal 13: 569-597. doi:10.1007/s00004-011-0083-3.

Meek, Harold Alan. 1988. Guarino Guarini and his Architecture. New Haven: Yale University Press.

Norberg-Schulz, Christian. 1985. Late Baroque and Rococo Architecture. Milan: Electa.

Norberg-Schulz, Christian. 1993. Kilian Ignaz Dientzenhofer y el Barroco Bohemio. Vilassar de Mar (Barcelona): Oikos Taus.

Otto, Christian F. 1979. Space into light: The Churches of Balthasar Neumann. Cambridge, MA: The MIT Press.

Pius V. 1570. Quo Primum. http://www.papalencyclicals.net/Pius05/p5quopri.htm.

Rosin, P. L. and E. Trucco. 2005. The amphitheatre construction problem. Incontro Internazionale di Studi Rileggere L'Antico (Rome, 13-15 December 2004).

Rykwert, Joseph and Engel, Anne (eds.). 1994. Leon Battista Alberti. Milan: Olivetti and Electa.

Sandonnini, T. 1888. Il padre Guarino Guarini modenese. Atti e memorie delle reali deputazioni di storia patria per le provincia modenesi e parmensi ser.3, V. Modena.

Schmerber, H. 1902. Einige Nachrichten über Guarino Guarini. Monatshericht für Kunstwissenschaft and Kunsthandel II.

Serlio, Sebastiano. 1545. Il Primo Libro della Architettura. París.

Sinding-Larsen, Staale. 1965. Some Functional and Iconographical Aspects of the Centralized Church in the Italian Renaissance. Acta ad Archaeologican et atrium historiam pertinentia, vol.II. Roma.

Smith, G.E. Kidder. 1990. Looking at Architecture. New York: Harry N Abrams.

Tavernor, Robert. 1998. On Alberti and the Art of Building. London and New Haven: Yale University Press.

Varriano, John. 1990. Arquitectura Italiana del Barroco al Rococo. Madrid: Alianza.

Vilímková, M., J. Brucker. 1989. Dientzenhofer. Eine bayerische Baumeisterfamilie in der Barockzeit. Rosenheim: Rosenheimer Verlagshaus.

Voelker, Evelyn Carol. 1977. Charles Borromeós Instructiones Fabricae el Supellectilis Ecclesiasticae, 1577. PhD. Universidad de Siracusa.

Volpi Ghirardini, Livio. 2015. The Numerable Architecture of Leon Battista Alberti as a Universal Sign of Order and Harmony. In: Architecture and Mathematics from Antiquity to the Future, Kim Williams and Michael J. Ostwald, eds. Cham: Springer, vol. I, pp. 645-662.

Wiesneth, Alexander. 2011. Gewölvekonstruktionen Balthasar Neumanns. Berlin: Deutscher Kunstverlag.

Víctor Compán became an architect in 2000 following study at the School of Architecture of the University of Seville (Spain). He has been in professional practice since 2000. In 2001, he became Assistant Professor in the School of Architecture of Seville, as part of the Department of Mechanics of Continuous Media, Theory of Structures and Ground Engineering. In 2012, he earned a PhD with a dissertation on structural behavior of complex geometries in Central European Baroque and, in the 
present, his research is focused on the study and analysis of historical structures, especially masonry structures.

Margarita Cámara was trained as an architect at the University of Seville (Spain), graduating in 2001. She began as Assistant Professor of the University of Seville, as part of the Department of Mechanics of Continuous Media, Theory of Structures and Ground Engineering, in 2002. In 2011, she earned a PhD with a dissertation entitled "New structural concepts in the architecture of the twenty-first Century". Since 2012, her research has mainly been focused on the study and analysis of historical structures.

Francisco González de Canales (PhD with cum laude, 2007; Master in Design with Distinction, 2007; Architect, 2001) studied architecture at ETSA Seville, ETSA Barcelona and Harvard University, and worked for Foster + Partners and Rafael Moneo. He is co-director of award winning practice Canales \& Lombardero, professor of Architectural history and theory at the ETSAS and unit master and diploma thesis supervisor at the Architectural Association (AA) in London. He was AACP coordinator at the AA (2008-2012) and director of Neutra Magazine (2002-2006). He is author of more than 30 scientific articles. Among his recent publications are First Works (2009), Experiments with life itself (2012) and Rafael Moneo: A Theory through Practicing (2013). 